\title{
\.
}

\section{THINKING IN THE MAKING: 3D DESIGNING AND PRINTING WITH YOUNG CHILDREN AND THE CREATION OF THRESHOLDS FOR LEARNING}

\author{
M. Cabral (Columbia University Teachers College - UNITED \\ STATES) \\ cabral2etc.columbia.edu \\ S. Justice (Columbia University Teachers College - UNITED \\ justicedtc.columbia.edu
}

\begin{abstract}
Through the exploration of digital 3D design and printing with preschool aged children, this presentation investigates the use of this emerging technology as a medium and material for thinking. Through the observation of the ways in which preschool children interact with digital 3D design and printing, the researchers question the role of materials and techniques in learning and artistic development, and consider notions of agency, ownership, and creativity in the light of psychological theories of learning (Piaget, Gardner).
\end{abstract}

As educators, our level of comfort with different media often dictates the types of activities and resources we make available to our students. Moreover our educational expectations may be influenced not only by our experiences with specific materials, and by our familiarity with them, but also by our unquestioned adherence to techniques that were available to us as school children. As a result, this often means that beliefs about the pedagogical value of new tools and materials go unexamined. In this study, we explore digital materials, particularly digital 3D design and printing, as examples of resources that are often overlooked in educational settings, especially with very young children.

The development of preschool-aged children is often regarded to occur in strictly linear and sequential stages. One critique of that framework is that it imposes pedagogical 


\section{४|}

ceilings as to the concepts that children in each stage are supposed to be able to understand. Consequently, it follows that learning experiences offered to students might be limited in their open-endedness and range of possibilities.

This paper presents an exploratory study based on the assumption that children are capable of engaging complex concepts through digital materials and media, including 3D design and printing. The researchers claim that these activities provide thresholds for learning that children can take ownership of, rather than stage-appropriate ceilings that inhibit expectations.

The researchers worked with a group of preschool children attending an Early Childhood Program nested in a graduate school of education in New York City. The children, girls and boys aged between 3 and 5 years old, have had many experiences with artmaking in different media and are used to work in small groups. Attending an early childhood center with a playbased curriculum where importance is given to each child's interests, they are used to question the world around them in different ways and to have their voices being heard.

keywords: art education, early childhood, 3d designing and printing.

Marta Cabral, Instructor of Art \& Art Education, Art for Classroom Teachers. Marta Cabral has been professionally teaching in classrooms and other settings for over 16 years. Having taught in Early Childhood, Elementary Education, and Graduate school levels, her rich and wide experiences as an educator allow her to relate to professionals in diverse contexts and different grade levels. Her many experiences as an educator (in America, Europe, and Asia) include classroom teaching; coordinating early childhood programs in early childhood and in art, for infants, toddlers, preschoolers, and kindergartners; and consultancy and training for educators and art educators. At Columbia University's Teachers college, 


\section{Rerysta \\ A. APOTHEKE}

Marta's current experience in teaching and supervising future educators (both preK-12 art teachers, and general education early childhood teachers) provides her additional insights into professional development and possibilities of art integration in the core curriculum. Marta holds several degrees in education that have examined Early Childhood Education and Art Education, including Masters degrees in Art and Art Education, and in Educational Sciences. Some other academic degrees Marta holds include Elementary Education and Adult Education. She is currently undergoing doctoral studies at Columbia University's Teachers College in the Interdisciplinary studies Program, grounding herself and her work both in the Art and Art Education, and in the Early Childhood Education Programs. As an educator and a researcher, Marta regularly presents her work at national and international conferences, and has several publications in the field of education.

Justice Sean, Instructor Ed.D.C.T. in Art Education. Teachers College, Columbia University. New York. (2015)

Dissertation: Learning to Teach in the Digital Age: Digital Materiality and Paradigms in Schools. M.A. Studio Art, Photography. New York University \& the International Center of Photography. New York. (1987)

B.A. English Literature. Catholic University of America. Washington D.C. (1983) 